\title{
A EXALTAÇÃO FEMININA NA OBRA DE ALBERTINA BERTHA
}

Bruno Lima

Resumo: $O$ presente artigo resgata Exaltação, romance de estreia de Albertina Bertha, publicado em 1916 com boa recepção da crítica e que, posteriormente, caiu no ostracismo. Ao analisar o romance, pretendemos lançar luz sobre a obra de modo a repercutir positivamente a literatura de autoria feminina, normalmente à margem do cânone, e levantar algumas questões pertinentes não apenas ao romance, mas à sociedade patriarcal na virada do século XIX para o XX. A protagonista Ladice é exemplar da luta feminista pela igualdade de gênero e icônica da introspecção feminina. Para um maior aprofundamento analítico, trabalhamos com o pensamento de Nietzsche, filósofo muito apreciado pela autora e bastante citado no romance. Os conceitos de apolíneo e dionisíaco servem como alicerce para o entendimento da personagem, cuja introspecção é flagrante. Também utilizamos textos críticos sobre o feminino de modo a dar mais subsídios para a compreensão do tema central no romance de Albertina Bertha.

Palavras-chave: Cânone. Autoria Feminina. Albertina Bertha. Exaltação.

Abstract: This article rescues Exaltação, Albertina Bertha's debut novel, published in 1916 with good critical reception and that was ostracized afterwards. By analyzing the novel, we intend to enlighten the work in order to positively reflect the female authorship literature, usually outside the canon, and to raise some questions pertinent not only to the novel, but to the patriarchal society at the turn of the 19th to the 20th century. The protagonist Ladice is a portrait of the feminist struggle for gender equality and of the iconic female introspection. For a more indepth analysis, we consider Nietzsche's line of reasoning, a philosopher that is highly appreciated by the author and widely quoted in the novel. The concepts of Apollonian and Dionysian serve as a foundation for comprehending the character, whose introspection is striking. We also use critical texts on the feminine to provide more information towards the understanding of the central theme in Albertina Bertha's novel.

Keywords: Canon. Female Authorship. Albertina Bertha. Exaltação. 
O cânone literário brasileiro necessita de revisões de modo a ressignificar obras de qualidade e até então muito pouca conhecidas, senão de todo olvidadas. Dentre os títulos relegados ao ostracismo, certamente os de autoria feminina constituem maior número, haja vista a formação do cânone ser feita por homens e para homens, isto é, a literatura escrita por mulheres pouco apreço recebeu dos formadores e mantenedores da Inteligência nacional. Uma breve análise nos principais manuais de história da literatura brasileira ratifica a marginalidade de nossas autoras, com raras e breves alusões a um número reduzido de obras merecedoras de análise. Buscar razões para o privilégio de autores homens e a quase absoluta ausência de mulheres que deixaram obras de valor para as nossas letras encontraria resposta no âmbito sociológico, que foge ao interesse presente; basta que concordemos ser a sociedade patriarcal a dominante, na qual ao homem cabia o espaço público e laboral e à mulher o espaço privado e doméstico, ainda que estejamos, atualmente, progredindo nesse sentido.

Felizmente, é crescente o número de pesquisadoras a escreverem sobre a autoria feminina, bem como é significativo o número de autoras a publicarem na atualidade. A crítica feminista, que ganha relevo a partir do pós-estruturalismo 
e da decorrência dos estudos culturais, tem sido importante ao trazer a público escritoras até então ignoradas pelo cânone vigente, não pela simples questão de gênero, mas sobretudo por redescobrir obras e autoras de peso para a literatura brasileira. A respeito do cânone, «é vital resgatar, a favor do feminino, todas aquelas vozes descanonizantes (incluindo as masculinas) que liberam leituras heterodoxas, capazes de subverter e pluralizar o cânone" (RICHARD apud FIGUEIREDO, 2020, p. 85). Para iluminar uma literatura posta à margem, analisaremos Exaltação, romance de Albertina Bertha publicado em 1916 e que obteve grande repercussão à época. A escolha desse romance ilustra muito bem três pontos que julgamos importantes: restabelecer uma leitura analítica de obra cuja recepção foi bastante promissora quando de sua publicação; dar visibilidade a um texto que, além de escrito por uma mulher, trabalha amiúde a distinção entre gêneros; e analisar a forma como uma protagonista mulher é construída sob a ótica feminina.

Para atingir os objetivos propostos, a escritora Albertina Bertha tem importância capital. Nascida no Rio de Janeiro em 1880, faleceu na mesma cidade no ano de 1953. Em vida, recebeu educação privilegiada, chegando a estudar línguas, estética e filosofia, além de participar ativamente 
na imprensa, com publicações nos periódicos $O$ Jornal, Jornal do Comércio, O País, O Malho, A Noite, dentre outros. Sua contribuição intelectual não se restringiu aos textos publicados em jornais e revistas, haja vista a participação ativa em grêmios culturais e na Sociedade de Homens de Letras, sob indicação de Olavo Bilac. Ela não se limitou a escrever ficção e tem um conjunto importante de ensaios publicados posteriormente em dois volumes com o título Estudos (primeira e segunda séries). Nelly Novaes Coelho, em seu importante Dicionário crítico de escritoras brasileiras, apresenta um verbete para Albertina Bertha, mas abstém-se de tecer comentários sobre Exaltação, romance de estreia da autora, e analisa apenas Voleta, seu terceiro romance. Anna Faedrich (2017) é a pesquisadora que se deterá com mais cuidado analítico sobre o romance em questão, dedicando não apenas sua pesquisa de mestrado sobre ele, como também, na Fundação Biblioteca Nacional, organizando uma edição crítica sobre a obra de estreia da escritora com o objetivo de tornar mais acessível sua leitura.

O enredo de Exaltação, em um primeiro momento, pode parecer banal, pois trata-se de uma jovem muito bem educada e proveniente de uma família tradicional que necessita render-se à vontade paterna e materna de 
um casamento por conveniência, sem quaisquer premissas amorosas. A protagonista Ladice mostra-se, de início, avessa e crítica às convenções sociais e demonstra fugir do paradigma comportamental que cabia à mulher na virada do século XIX para o XX. Apesar de não amar o pretendente escolhido pela família, vê-se obrigada a cumprir o desejo familiar e rende-se ao matrimônio, mas sente-se apaixonada por outro homem, o poeta Teófilo, com quem manterá um relacionamento adúltero. O adultério, comum em grandes obras da literatura brasileira oitocentista, reaparece, mas dessa vez sob a ótica feminina e sem as agruras do olhar patriarcal presentes, por exemplo, em Dom Casmurro, de Machado de Assis, no qual Capitu é exilada pelo marido Bento Santiago, narrador do romance. Diferentemente de Capitu, Ladice possui voz, apesar do romance ser construído em terceira pessoa - aqui, a participação de um narrador onisciente é interessante porque ele aproxima-se da personagem, muitas vezes dando a entender que comunga com o pensamento de Ladice. Anna Faedrich utiliza o conceito de psiconarração, que "é o discurso do narrador sobre a consciência de uma personagem", para enfatizar a aproximação existente entre ambos, pois, "dessa forma, a psiconarração permite que o narrador, no contexto de terceira pessoa, volte o seu olhar para o interior das personagens, 
podendo, assim, emitir julgamentos durante a narrativa, buscando sempre a individuação e não a generalização" (2017, p. 98). Como veremos mais à frente, essa individuação é um ponto-chave para a construção de Exaltação.

Um casamento arranjado, cujas características aproximam-se da mercantilização da mulher, não é novidade alguma, seja social, seja literariamente. Mary Del Priori (2009), em estudo referente à condição feminina no Brasil Colônia, já alertava que a mulher deveria manter o amor fora da condição conjugal e que, mais que amar seu marido, era necessário suportá-lo. Essa tradição chega ao tempo de Ladice, cuja mãe afirma sem meias palavras, irritada com os modos revolucionários da filha: "- Como são tolas as mulheres de hoje! Só falam em amor. No meu tempo, uma moça não se atrevia a pronunciar essa palavra ao lado de sua mãe... É bem uma era de perdição..." (BERTHA, 2015, p. 44). A Senhora de Santo Hilário, tão vítima quanto fora sua mãe, pretendia infligir o mesmo destino para a sua filha, sem a percepção do mal que sofrera e que também sofrerá Ladice. De acordo com Rose Marie Muraro e Leonardo Boff, não é surpreendente a manutenção do status quo por parte da Senhora de Santo Hilário, porque "tradicionalmente homens e mulheres casavam-se para desempenhar papéis 
que a sociedade lhes destinava. O homem procurava uma mulher que cuidasse dele e dos filhos e a mulher procurava um provedor. [...] Os papéis eram bem definidos" (2010, p. 183). Não podemos esquecer que o casal de Santo Hilário era uma das famílias mais tradicionais de seu tempo, sugerindo assim a preservação do casamento como forma de assegurar um marido condizente socialmente com Ladice, sem espaço para o amor.

O amor de Ladice, como dito, pertencia ao poeta Teófilo e será vivido fora do casamento, em uma relação adúltera que poderia despertar a desonra da jovem, e a leva ao suicídio. O fim trágico, todavia, não obedece ao moralismo ou à punição da mulher, como ocorre em Machado e em Alencar, por exemplo; antes, Ladice abdica de viver justamente por causa do amor, resolução levada a cabo após ler carta da esposa de Teófilo a reclamar a ausência do marido. Nesse momento, fica claro o sentimento de que seu amor clandestino não poderia impedir a felicidade de outra mulher, sobretudo sendo esta esposa do poeta e mãe de sua filha, em uma espécie de sororidade, termo bastante atual. Ao longo do romance, o pensamento iconoclasta de Ladice cede às convenções sociais, como se faltasse força para levar adiante suas convicções, afinal, o regime 
patriarcal, seu adversário, continha um papel solidificado cujo empenho da protagonista era ineficiente para vencer. Segundo a própria Ladice, "Com certeza, a minha vontade não prevalecerá, apesar da inteligência, e das ousadias que trago... Oh! A revolta contra o rigor dos que me governam... Obedecer, obedecer eternamente..." (BERTHA, 2015, p. 19). Mais à frente, em conversa com seu primo João Dalmada, responde-Ihe, acerca do casamento, de modo a observar a consciência de que sua luta era inglória e desigual: "- Sou dela [da sociedade] apenas um átomo isolado, alheio a tudo; vivo sob o meu sol, o meu único destino, o meu pedaço de terra..." (BERTHA, 2015, p. 31).

É interessante observar que cabe a um poeta o amor de Ladice, afinal, "só os poetas, os místicos - aqueles que integram mente e corpo -, dentre os homens são os que têm acesso à mulher. Estes não são incompatíveis com ela», escrevem Muraro e Boff (2010, p. 192) ao criticarem o pensamento de Lacan. Segundo estes autores, é a partir da educação recebida pelas mulheres que elas entram definitivamente nos sistemas simbólicos masculinos, mas de forma diferente, ou seja, não apartam razão e emoção, distinção comumente feita pelos homens. E muito bem educada foi Ladice, tal qual Albertina Bertha. É possível 
fazer correlações entre a vida empírica da autora e a da personagem, mas infelizmente a ausência de dados biográficos seguros impedem uma maior aproximação, muito embora não seja nosso interesse enveredar por uma hermenêutica biográfica.

A formação intelectual de Ladice, que afirma inclinação pelas ciências e pela filosofia, fazia com que o interesse pelo homem não se desse por atributos físicos, como ratifica o narrador: "No homem não era a beleza física que a seduzia, mas a inteligência, a erudição, o caráter" (BERTHA, 2015, p. 21). Além disso, Teófilo, como poeta, é "o artista [que] leva a sua perfeição, a sua volúpia dionisíaca em busca de arte, de sonho, de inspiração" (BERTHA, 2015, p. 35). Em outro momento, Xavier, amigo de Teófilo, diz-Ihe: "- Mas, Mestre, são só os poetas que amam assim, com essa veemência dominadora. É uma morbidez inerente unicamente aos senhores; nós, outros, os vulgares, somos tímidos" (BERTHA, 2015, p. 184). Em uma palavra, foge das características metonímicas e apolíneas dos homens, tornando-o singular, assim como Ladice, cuja interioridade é inalcançável. Teófilo, ao mimetizar e poetizar a realidade, a recria de maneira a fugir daquilo que Ladice desprezava e difere dos outros homens, vulgares; para suportar sua realidade, urgia Ladice 
transformá-la, bem como o destino comum a todas as mulheres de seu tempo. Em conversa com sua prima Dinah, que possuía forte veia religiosa, a protagonista irrita-se:

- Como me irrita essa tua passividade, aprendida em um convento. Aqui, em casa, esquecem-se de que sou uma mulher... Querem-me sem inclinações, sem opinião, igual a todos. Meu Deus! É preciso que eu siga a trilha comum, que diga sim, após o sim, de toda uma geração, que tenha o pensamento que vinte e mil cérebros já elaboraram... (BERTHA, 2015, p. 20, grifo da autora)

É evidente, desde o início do romance, a inconformidade de Ladice quanto ao papel correspondente à mulher. $\mathrm{Na}$ resposta a Dinah, ela indica que nem todas as mulheres são iguais, cada uma exercendo a sua própria individualidade, sem a necessidade de obter as mesmas obrigações e orientações passadas de geração em geração a todo corpo feminino, obedientes aos cérebros responsáveis pelo modo submisso que ela deveria também seguir. Não é sem razão que para João Dalmada "ela the parecia como sendo um tipo perfeito de mulher: esquisito, singular, com cintilações de imprevisto, de inédito. Lembrava-lhe certas figuras femininas vistas em alguns salões estrangeiros" (BERTHA, 2015 , p. 32). Porém, o estranhamento que a singularidade dela lhe causa deve-se justamente ao afastamento da 
passividade inerente da mulher de então, descortinando uma pessoa estranha e inatingível.

Anna Faedrich (2017) situa Exaltação como um romance de introspecção na literatura brasileira. Para a pesquisadora, as obras dessa linhagem foram excluídas do cânone devido à necessidade de firmar nossa literatura autônoma em relação à portuguesa no século XIX. Assim, critérios extraliterários receberam primazia em relação a paradigmas intraliterários e estéticos. As obras que privilegiaram discussões acerca do caráter social e nacional receberam holofotes, ao passo que aquelas preocupadas em ressaltar a subjetividade e a interioridade dos sujeitos ficaram à sombra, à margem. Para Anna Faedrich, esse é o grande equívoco da crítica especializada, porque

a leitura crítica feita a partir da relação entre literatura e sociedade não dá conta dos recursos narrativos e dos procedimentos presentes na literatura dessa linhagem fluxo de consciência, monólogo interior, técnicas de apresentação da consciência das personagens, subjetivação do conflito social do herói, etc. (2017, p. 37-38)

Concordamos que Exaltação se adéque aos romances de introspecção, mas não necessariamente tal filiação exclua a discussão do caráter social de seu tempo. Naturalmente, não se trata no romance de Albertina Bertha da discussão sobre 
nacionalidade, tão cara no século XIX, porém, é flagrante a crítica ao patriarcado e à situação da mulher. As menções ao Brasil político, por assim dizer, são rápidas e podem passar desapercebidas a um leitor apressado, mas a família de Santo Hilário, detentora de título de nobreza, sofreu com a mudança do regime, pois "a mudança de governo os afastara totalmente da sociedade; visitavam, apenas, alguns amigos do antigo regímen" (BERTHA, 2015, p. 36). Ao final do romance, em viagem a Petrópolis, há discurso encomiástico a D. Pedro II, o que sugere saudosismo de um passado tradicional e conservador, ao passo que Ladice é afinada com os novos tempos, haja vista seu caráter revolucionário. É o poeta quem laureia a modernidade, em conversa com o amigo João Dalmada, ao afirmar que, "atualmente, o Rio está habitável. Há espaço, ar, higiene..." (BERTHA, 2015, p. 162), em clara alusão à Belle Époque. Contudo, pensamos que Anna Faedrich tem razão ao incluir Exaltação no rol de romances de introspecção na literatura brasileira.

Ladice é uma jovem muito bem educada, culta, bonita e introspectiva. Os demais personagens, sejam os masculinos, sejam os femininos, não conseguem compreendê-la presos que estão a um modelo de mulher ideal que necessita ser sempre o mesmo, isto é, uma esposa dedicada, fiel, mãe de 
família e zelosa dos afazeres domésticos, características de todas as mulheres de boa reputação e status social. As demais personagens do romance de ambos os sexos desconhecem o eu profundo de Ladice, cuja idiossincrasia é de conhecimento apenas do leitor. Vale sublinhar que, apesar de ignorarem quem de fato ela é, todos os homens que se aproximam de Ladice se apaixonam por ela. Em outras palavras, enxergam apenas a sua beleza exterior e assim se encantam. Pouca relevância teria o seu âmago pois cabia às mulheres a representação do mesmo papel: a mantenedora da ordem doméstica. Nesse sentido está a importância de Albertina Bertha, que questiona de forma veemente o machismo dominante daquela sociedade e apresenta uma personagem revolucionária e distante da estereotipia feminina usual. Ladice é capaz de rebater à altura os comentários machistas graças à sua cultura e ao seu conhecimento filosófico. Para Maurício Silva, a relevância de Albertina Bertha para a literatura brasileira reside no

tratamento diferenciado dado à temática da libertação feminina. Numa época em que a mulher padecia de limitações nos mais elementares direitos do ser humano, Albertina Bertha toma as dores da minoria de que fazia parte e coloca sob suspeição todos os mais empedernidos preconceitos em relação à mulher vigentes na época. (SILVA, apud FAEDRICH, 2017, p. 56) 
E a própria autora, como não poderia ser diferente, sofrera com os mesmos preconceitos, basta observar um pequeno fragmento de entrevista dada a Francisco de Assis Barbosa:

Mamãe era moça de finíssima educação. Estudara na Inglaterra. Recebia muito bem. Nossa casa estava sempre cheia de gente. Tínhamos todos os dias convidados para o jantar. Mamãe dava às filhas educação inglesa. Às vezes papai dizia: "- Ó Chica, você quer fazer dessas meninas rapazes." (BERTHA, apud FAEDRICH, 2017, p. 43)

No romance, há diálogo entre Ladice e seu marido que ilustra a experiência empírica da autora e que pode ser extensiva a qualquer mulher naquela sociedade. Assim Francisco a recrimina quanto às suas ideias extravagantes: “- São os efeitos da educação viril que recebeste... É um mal terrível, esse modernismo, esta mania tola, de instruir-se a mulher, como se fora um rapaz" (BERTHA, 2015, p. 174). Tanto em sua vida pessoal quanto na de sua personagem, a educação esmerada dada a mulheres nada mais era do que assunto para homens, mas nem por isso a escritora deixou de estudar, inclusive dando palestras, dentre as quais sobre a filosofia de Nietzsche. O filósofo alemão era muito apreciado pela autora, que inclui em Exaltação mais de uma epígrafe sua, além de referências diretas ao pensador no romance. A recorrência ao pensamento nietzschiano, inclusive, 
rendeu crítica de Lima Barreto. Em prefácio à edição crítica organizada por Anna Faedrich, Ana Maria Lisboa de Mello (apud BERTHA, 2015, p.12) cita uma opinião do autor acerca do livro de conferências Estudos, na qual ele afirma que as ideias de Nietzsche exaltariam "a brutalidade, o cinismo, a amoralidade, a inumanidade e, talvez, a duplicidade". A crítica é a Nietzsche, mas poderia ser extensiva a Exaltação, romance prenhe do pensamento do alemão. Acreditamos, porém, ao revés de Lima Barreto, que os conceitos de apolíneo e dionisíaco são pertinentes para entendermos o romance em análise.

Esteticamente, Anna Faedrich (2017) situa Exaltação no Decadentismo, cujo um dos pais seria justamente Nietzsche. Assim, de acordo com a pesquisadora, é possível entender o mergulho no eu profundo de Ladice. Acreditamos válida e endossamos a leitura de Anna Faedrich, mas optamos por uma nova hermenêutica: a contraposição dos deuses Apolo e Dioniso ajudaria mais a contento a observar a interioridade de Ladice, por um lado, e a exterioridade, por outro. A crise do sujeito postulada pelo filósofo alemão fundamenta a crítica contida no romance de que as mulheres devem obedecer o mesmo paradigma comportamental. Como dito anteriormente, os homens do romance, mesmo sem 
conhecerem a intimidade de Ladice, se apaixonam por ela devido à sua beleza. Eles só veem o exterior e, nesse sentido, pode-se afirmar que Ladice nada mais é do que uma visão apolínea, uma vez que Apolo é o deus do brilho, da aparência e da ilusão, assim simbolizando o mundo da representação, da forma, da individuação. A jovem instruída, bem educada, proveniente de uma classe social privilegiada e bonita seria uma forma perfeita para a construção social da mulher, pois, nas palavras de Roberto Machado, "a pulsão apolínea diferenciadora cria formas e, assim, individualidades. O povo de Apolo é o povo das individualidades" (2006, p. 206). Pode parecer haver um equívoco aqui, uma vez que Ladice, como as mulheres em geral, não detinham o direito básico de ser, senão como o modus vivendi comum a todo sexo feminino. No entanto, é apenas a aparência que é colocada em relevo, cuja diferença entre as mulheres se dá apenas formalmente. Ladice é um indivíduo diferente de Dinah, que por sua vez difere da Senhora de Santo Hilário e assim sucessivamente. São essas individualidades as vistas pelos homens, sem se atinarem para algo mais profundo do que elas aparentam. É exemplar nesse sentido a cena em que o cronista Armando solicita a seu amigo Jorge que o apresente a alguma dama da sociedade para figurar em evento de caridade. De imediato Jorge recomenda Ladice 
e Armando duvida da descrição do amigo e pede para conhecê-la pessoalmente. No dia seguinte,

a porta abriu-se silenciosamente. Ladice apareceu formosa, radiante. Enquanto era apresentado, Armando esforçava-se por ocultar a admiração; seus olhos colavam-se naquele corpo que tinha o grande frêmito da vida; subiam, desciam, entravam-Ihe pela pele, sem poder sair, sem ainda distinguir traços de outros traços, não vendo senão um rosto feito de lírios ardentes e uns cabelos flutuantes, onde Cupidos pareciam brincar em suas ondas.

Pouco a pouco, seus olhares, oblíquos a princípio, foram fitando, parando, retendo, suspendendo-se nessa fragilidade branca e rósea que encerrava a alma tão cheia de primaveras esplêndidas. (BERTHA, 2015, p. 90)

A primeira visão de Armando contemplava apenas o corpo de Ladice, pois ainda não haviam trocado palavra alguma. Como conhecê-la de fato, para além da aparência, com a certeza de ela encerrar "alma tão cheia de primaveras esplêndidas"? Certamente não era possível. De acordo com Muraro e Boff (2010), uma das distinções entre homem e mulher é que aquele separa sexo do afeto, enquanto esta os une. O que Armando sentiu, em verdade, foi desejo por Ladice, posto que ainda não a conhecia. Vale sublinhar que o amor de Ladice por Teófilo iniciou-se com a leitura de sua poesia, sem o conhecer pessoalmente, mas, para ela, "a arte 
é imortal, é inveterada [...]" (BERTHA, 2015, p. 80). Adicionase a essa compreensão de Ladice o fato da poesia atingir de forma profunda o eu do leitor, uma forma dionisíaca. Para Nietzsche, "ambos os impulsos, tão diversos, caminham lado a lado, na maioria das vezes em discórdia aberta e incitandose mutuamente a produções sempre novas" (1992, p. 27). Se o apolíneo e o dionisíaco caminham lado a lado, vejamos como se dá o dionisíaco em Exaltação. Ao contrário de Apolo, Dioniso é o deus do caos. Seria a essência do dionisíaco a responsável por não ficarmos na ilusão da aparência, força presente na arte, tão cara a Ladice. A dialética entre artista e obra de arte, no pensamento de Nietzsche, faz com que nos aproximemos do dionisíaco. Assim,

agora o escravo é homem livre, agora
se rompem todas as rígidas e hostis
delimitações que a necessidade, a
arbitrariedade ou a "moda impudente"
estabeleceram entre os homens. Agora,
graças ao evangelho da harmonia universal,
cada qual se sente não só unificado,
conciliado, fundido com o seu próximo,
mas um só, como se o véu de Maia tivesse
sido rasgado e, reduzido a tiras, esvoaçasse
diante do misterioso Uno-primordial.
(NIETZSCHE, 1992, p. 31)

Parece-nos que é desse modo que chegamos a compreender Ladice em sua totalidade, para além da beleza 
apolínea que encantava os homens; também acreditamos que o curto excerto acima exprime o desejo tanto de Ladice quanto de Albertina Bertha de se igualarem aos homens e libertarem-se da "escravidão" à qual estavam submetidas. É de forma caótica que a nossa protagonista pretende reverter o status quo e inquietar os personagens de Exaltação. Como já discutimos, ela casa-se à revelia, sem amor, apenas para cumprir a ordem estabelecida por sua família. Mas não abdica do amor e entrega-se a uma relação adúltera, sem discussões moralistas sobre seus atos. Ainda na segunda página do romance, assim ela se afirma em diálogo com Dinah: “- É simplesmente efeito de uma natureza tropical e de leituras clássicas, fortes. Que importa, Dinah, que seja a primeira a rasgar os preconceitos e as hipocrisias? Querida, tudo evolui. Mulher hoje é espírito até nos gestos; é breviário dos deuses, entendes?" (BERTHA, 2015, p. 20). Breviário dos deuses, assim, em minúscula, não seria equivalente a Apolo e Dioniso? É o filósofo alemão quem a ajuda a criticar a moral e, ao mesmo tempo, mais à frente, fazer um retrospecto quanto à sua própria conduta. Em diálogo com o marido Francisco, em que este defende a moralidade da sociedade e, por conseguinte, o recato da mulher, de forma acentuadamente preconceituosa, ela assim responde: “- A moral - e Ladice sorriu - é a veste fornecida por cada 
século para colorir as convenções humanas então na moda... Ela varia como o tempo, como qualquer mulher histérica" (BERTHA, 2015, p. 174). Essa resposta espanta o marido, que a chama de revolucionária. Em outro episódio, Nietzsche oferece-lhe um ponto de vista para uma autocrítica, nas palavras do narrador:

A seguinte definição descoberta num livro de Nietzsche calou-lhe até aos penetrais do senso como um obus, em flamas: "a verdadeira moral é a certeza instintiva da ação". Daí Ladice depreendeu com tristeza e alegria que sua vida passada, que considerava um sacrifício, um ato superior de abnegação cristão, era simplesmente a concatenação de mentiras e hipocrisias, a aparência falsa de uma virtude que não existia. Fora vivida contra a sua vontade, as suas tendências e inclinações, forçada pelas circunstâncias, pela falta de insurreição de um amor alucinante ao seu alcance, inteiro seu e doidamente correspondido... O seu desvario por Teófilo aumentava... (BERTHA, 2015, p. 186)

É certo que por um lado Ladice não se insurgira contra o casamento, aceitando a determinação familiar e entregando-se à infelicidade, agindo, dessa forma, contra suas convicções, mas por outro lado ela não possuía força suficiente para se rebelar e caminhar na contra-mão das convenções sociais, como fizera Lóri, personagem de Uma 
aprendizagem ou o livro dos prazeres, de Clarice Lispector, esta sim escritora canônica com merecimento e igualmente introspectiva. Em resposta a Ulisses de por que deixara sua cidade, Lóri responde: “- É que eu não queria... não queria me casar, queria certo tipo de liberdade que lá não seria possível sem escândalo, a começar pela minha família, lá tudo se sabe, meu pai me manda mesada porque o dinheiro da escola eu não poderia -" (LISPECTOR, 1998, p. 49-50). A realidade de Ladice era mais dura nesse sentido, pois jamais conseguiria sair de casa e receber ajuda pecuniária paterna. Restava-Ihe obedecer... A citação de Nietzsche, ao mesmo tempo que a entristece por perceber que colaborara com a mentira e a hipocrisia, a alegra porque agora vive enfim o amor de Teófilo, despreocupando-se com quaisquer moralismos de uma sociedade retrógrada e patriarcal, incapaz de dar à mulher poder de escolha. Nesse momento exerce enfim sua preferência em nome da transgressão e da felicidade.

Em outro episódio, dessa vez em diálogo com seu primo João Dalmada, assim Ladice redargui o interlocutor que a acusara de faltar-Ihe coerência, senso, reflexão, sinceridade: "- Se eu fosse assim, deixaria de ser a mulher que tanto aprecias. Nietzsche diz que o nosso maior encanto repousa justamente nesses defeitos... Ele não nos concebe sem 
a modalidade das paixões..." (BERTHA, 2015, p. 166). É evidente a presença do pensamento nietzschiano na obra de Albertina Bertha, sobretudo se considerarmos os textos teóricos que ela nos deixou e buscarmos mais exemplos que podem ser pinçados no interior do próprio romance. Porém, Albertina Bertha (apud FAEDRICH, 2017, p. 80) possuía senso crítico capaz de apontar problemas no filósofo em nome da luta feminista na qual estava imbuída, como notamos no fragmento de sua conferência cujo título é o nome do pensador alemão:

Nietzsche não teve de nós outras, mulheres, uma opinião cabal, exata; apenas beirou a realidade da nossa estrutura moral. As suas referências são sombras ocas, ironias para provocar o sorriso, ou, talvez, vinganças de despeitado, floração de mau humor... são chicotadas de quem nunca foi amado, de quem nunca recebeu o carinho, a meiguice, a febre de uma mulher de espírito e beleza. Se ele se limitasse somente a condenar o feminismo como o maior dos flagelos europeus, se ele somente declarasse, como o fez, que quanto mais a mulher adquire direitos sociais, mais ela se aliena da mulher... estaríamos de pleno acordo, aplaudiríamos esse defensor da nossa linda fragilidade, dos nossos encantos máximos perante os homens... mas, não; quer-nos mentirosas, ignorantes, sem profundezas de engenho, apenas uma gata perigosa e bela, para a sedução do homem... entretanto, as duas únicas mulheres que amara, eram 
duas intelectuais, dois seres de mistério e de contradições magníficas. (apud FAEDRICH, 2017, p. 80)

O excerto acima é extenso mas ilustra muito bem a importância de Albertina Bertha e de Exaltação para a literatura brasileira, não apenas pelo rigor estético com que é escrito, mas principalmente por abordar, no começo do século $X X$, questões urgentes ainda agora no início do XXI. Não estivesse ausente do cânone literário, possivelmente a luta feminista atual encontrasse menor resistência e a pauta da autora encontraria eco mais cedo. É curiosa a subtração desse romance do cânone haja vista a grande repercussão que obteve na data de publicação, 1916. Segundo Anna Faedrich, em posfácio à sua edição crítica com a qual trabalhamos, a terceira edição do romance continha um prefácio de Araripe Júnior, um dos grandes e mais influentes críticos de que dispúnhamos, que escreveu: "Ainda não me restabeleci da surpresa que me causou Exaltação. Continuo a garantir que o seu livro será o mais vibrante dos romances publicados no último decênio" (ARARIPE JÚNIOR apud BERTHA, 2015, p. 229). Antes mesmo do prefácio, Araripe Júnior já enviara carta ao Jornal do Comércio reivindicando a publicação de Exaltação. A citação é longa mas importante para evidenciar a impressão inicial do romance: 
Solicitando do Jornal a inserção, nas suas colunas de honra, dos dois capítulos do romance Exaltação, escrito por D. Albertina Bertha, o meu fim é chamar a atenção para um dos talentos femininos que mais me tem impressionado. O romance Exaltação, no seu conjunto, apresenta, quer pela concepção, quer pelo estilo, qualidades extraordinárias. 0 poder descritivo da autora tem um cunho singular e o colorido da paisagem exibe notas fulgentes que recordam a escola dos coloristas italianos, e, às vezes, o modo do pintor inglês Turner. [...] Há um lirismo insóbrio! Mas é preciso não perder de vista que essa parte do livro contém justamente o delírio das folias, as comunicações de amantes, vítimas de uma formidável intoxicação pelo amor; além de tudo instruídos, cultos e devorados pela ansiedade de realização de um tipo ético ultra vires. O Jornal, publicando esses fragmentos, não fará senão concorrer para que no horizonte das nossas letras desponte um astro de primeira grandeza. (ARARIPE JÚNIOR apud BERTHA, 2015, p. 230)

Do mesmo modo que Exaltação foi laureado por Araripe Júnior, outros escritores de prestígio igualmente o recomendaram, conforme enumera Anna Faedrich. Porém, houve críticas em função do adultério e da emancipação feminina, temas tabus na data de publicação. Vejamos, portanto, alguns pontos que merecem destaque, nesse sentido, na obra de Albertina Bertha, com o desejo de que 
ela adquira novos leitores e saia do ostracismo, recuperando um lugar merecido no cânone literário brasileiro.

Exaltação é um romance transgressor ao colocar em xeque o local de subordinação da mulher e, sobretudo, ao tratar o adultério sob a ótica feminina. São várias as passagens em que é explícita a fala masculina de subjugação da mulher, sempre ancorada por arquétipos e estereótipos propícios ao patriarcado. Senão em todas, na maioria das cenas o homem trata Ladice como uma mulher apolínea, isto é, sem a devida subjetividade que the é inerente, razão suficiente para que Albertina Bertha tenha optado por escrever um romance de introspecção. $O$ que se passa na alma da mulher? Por melhores que tenham sido nossos escritores oitocentistas, mimetizaram o feminino sob sua ótica própria. As relações amorosas envolvendo homens não continham o moralismo em grau acentuado, sendo muitas vezes irônico, como percebe-se na prosa romanesca de Machado de Assis. É válido assegurar que o casamento também era um compromisso social para o homem, que não raro se casava sem amor, mas, diferentemente do que ocorria com a mulher, possuía direito de escolha. Em Memórias póstumas de Brás Cubas, de Machado de Assis, Virgília casa-se com Lobo Neves, mesmo com o acordo 
prévio firmado pelo pai de Cubas. No entanto, não deixa de ter uma relação extraconjugal com Brás Cubas, cuja narração não demonstra censura. Cabe ao leitor conhecer Virgília pela pena de um escritor que usa um narrador para mimetizar a mulher. Este é apenas um dentre inúmeros exemplos nas nossas letras. É evidente que a questão do adultério com penas rigorosas para as mulheres não se limita à literatura brasileira, basta lembrarmos, para citar apenas uma obra, As mil e uma noites. Não pretendemos aqui inviabilizar a criação de personagens femininas por escritores masculinos, mas chamar atenção para a importância de escritoras, possuidoras da vivência, falarem sobre as mulheres, principalmente em um mundo machista. Eurídice Figueiredo é feliz ao afirmar que "interessanos ver, dentro da perspectiva de uma crítica feminista, quais estratégias narrativas as escritoras dos séculos $X X$ e XXI usam a fim de fazer que suas personagens femininas sejam sujeitos de seu próprio discurso" (2020, p. 92). Já evidenciamos semelhanças entre episódios da vida empírica de Albertina Bertha com a de Ladice, no que diz respeito à educação da mulher; do mesmo modo, alertamos para a luta feminista da autora. Vejamos como isso se dá no romance de forma mais detida. 
O percurso atravessado por Ladice para viver o amor com Teófilo é pautado pelo machismo estrutural da sociedade. Todos os homens com quem ela interage emitem opiniões acerca da conduta moral necessária à mulher. João Dalmada aparece no romance como um homem esclarecido, cuja vivência na Europa Ihe dera ares mais cosmopolitas. Ele é o primeiro a servir de confidente à sua prima, cujos conselhos são despidos, em um primeiro momento, de machismo. Porém, apesar de uma roupagem aparentemente libertária, mantém uma postura moralista acerca da necessidade do casamento para a mulher, não para o homem, pois ele mesmo é um solteirão convicto que se sacia com variadas mulheres, mas sem firmar compromisso com nenhuma. Nesse sentido, o conselho de Teófilo é exemplar tanto da conduta de João quanto da temática do romance: "Sê solteiro a bem do feminismo [...]" (BERTHA, 2015, p. 161). O mesmo não poderia suceder com o sexo oposto. Quando Ladice confidencia-lhe o desejo de ser artista, ele responde que isso seria sua ruína moral. Para ele, a procriação era necessária para que o nome e o legado da mulher não se extinguissem nela própria, como se a individuação subjetiva feminina não bastasse por si só. João Dalmada sabe que Teófilo é casado e possui uma filha, mas isso em momento algum é censurável aos olhos de João, diferentemente da 
recriminação imposta a Ladice. Ao descobrir casualmente o amor clandestino de Ladice e Teófilo, ele deseja vingar-se, expor ao mundo a traição, revestido de duplo sentimento: o ciúme que nutria por sua prima e a obediência social, afinal, como ele mesmo afirma a Ladice, ela pertence ao marido e à sociedade. Rumina seu rancor nesses termos: “Oh! Dissimulação! Oh! Hipocrisia feminina! Hei de dizerIhe que Ihe descobri o segredo, a impureza... Oh! Amante febril que vem procurar o seu amante!" (BERTHA, 2015, p. 163). Tal reação não ocorreu em relação a Teófilo, homem casado, tampouco serviu como autocrítica devido às inúmeras relações furtivas que João Dalmada tivera ao longo de sua vida. A sociedade não punia nem via com maus olhos homens em relações extraconjugais, mas era implacável quando o cônjuge infiel era do sexo feminino. Na discussão que segue, Ladice contra-argumenta:

- Desconheces a violência da paixão? O que são virtude, honra, marido, sociedade, lealdade, ante este sentimento tão poderoso, tão louco, tão avassalante que os próprios moralistas e fisiologistas o atribuem antes ao sopro do gênio da espécie do que ao desejo do próprio indivíduo... Chamfort diz que os amantes neste caso são um do outro por natureza, que eles se pertencem por direito divino, apesar das leis e das convenções humanas... Perante a ciência, quem ama é um irresponsável... (BERTHA, 2015, p. 167) 
A necessidade de se adequar às imposições sociais, para Ladice, é intolerável, pois “a mulher não consegue construir uma persona, isto é, uma personalidade falsa no trabalho e outra em casa, e procuram menos o status e mais a realização pessoal" (MURARO; BOFF, 2010, p. 198). É correto afirmar que Ladice não trabalha, mas se levarmos em consideração que o seu labor é doméstico, como exigia a sociedade do início do século passado, pode-se afirmar que o casamento, para ela, constituía seu trabalho. Cabia a ela administrar os afazeres domésticos, recepcionar os convivas do marido, educar os filhos etc. É contra o papel que lhe destinaram e em obediência ao seu eu que ela entrega-se a Teófilo, incapaz de subtrair o desejo em nome da ordem moralista. Ao término do capítulo em que João a confronta e ela busca explicar sua conduta, este, então, sugere que ela abandone o marido e se dedique a viver o amor de forma plena e satisfatória, porém ela responde que é incapaz, pois Francisco, seu marido, morreria, pois a adora. Há culpa aqui, ou ao menos a interiorização da impossibilidade de fugir às amarras sociais, como ocorrera quando ela aceitara se casar; faltava-Ihe, enfim, levar a cabo a "tresvaloração de valores" a um nível definitivo (NIETZSCHE, 1995, p. 25). Contudo, não há o que recriminar em Ladice, pois hoje, 105 anos após a publicação de Exaltação, ainda há muito o que ser 
conquistado na igualdade de gênero, apesar dos avanços da luta feminista.

A respeito de seu casamento, Ladice anotou em seu diário, símbolo de uma escrita de si para si, introspectiva, resposta dada a João sobre o conselho de ser "sempre virgem, fechada em purezas": "- Serei intangível, qual Serva do Senhor." (BERTHA, 2015, p. 25). A sugestão do primo era a de manter a "pureza" até o casamento, de modo a não macular compromisso sagrado, ao passo que a resposta confirmava o desejo de não se entregar ao marido mesmo após consumado o casamento. Dito de outro modo, Francisco teria apenas o corpo de Ladice, cujo amor - e ela toda - pertencia a Teófilo. Francisco de Assis, homem bem visto e apreciado socialmente, não possuía Ladice, mas a representação daquilo que qualquer outra mulher desempenharia em seu lugar. Apenas exteriormente podiase acreditar na união do casal, pois o eu da protagonista permanecia alhures. Assim o psiconarrador refere-se à verdadeira situação da Senhora de Assis:

Olhando o marido, a sua consciência se conservava branca, luminosa, sem arestas e exprobações. Perante ele, a Sociedade, o Dever, ela se julgava resgatada... DeraIhe a virgindade, a inocência, motivos de orgulho e satisfação, fruições de inteligência e esteticismo... Embora nos arcanos de seu 
senso refugasse essas aparências falaciosas, nulas; mentiras decisivas, lealdades falsas, hipocrisias com ademanes de virtude... Francisco the havia possuído o corpo totalmente vazio dela. A sua verdadeira virgindade, as explosões de seus espasmos, o estranho de sua imaginação mórbida, os venenos de seu êxtase, a sua sede total, forte, ela ofertara, entregara a Teófilo, como eclosões intangíveis, frutos lídimos da Pureza. (BERTHA, 2015, p. 220)

A Senhora de Assis, para o marido, era como uma estátua cuja serventia era a da ostentação tão-somente; enfeitava o lar e, por extensão, conferia uma posição de relevo a Francisco perante a sociedade. O marido desconhecia sua esposa, cujo eu era só dela e a quem julgasse que devia possuir-lhe os sentimentos mais fundos e secretos, entregues apenas ao poeta, afinal, "Vós outros homens desconheceis a grandeza, a plenitude, a energia, a capacidade ilimitada de forças que fervem no coração feminino, quando ele está no auge do verdor" (BERTHA, 2015, p. 147). Lembremos que Ladice tinha predileção por homens eruditos e com caráter, qualidades ausentes em Francisco. Ele apenas cumpria sua função social, mas sem a verve própria aos poetas. Em busca de satisfação e alegria com o marido, entabula uma conversação sobre uma leitura recente que fizera, na qual um rapaz abandona 
esposa e filhos em nome de outra mulher, seu verdadeiro amor, que Ladice classifica como "ato heroico". Francisco ouve e responde de maneira escandalizada da seguinte forma: "- Não sei que gozo encontras em leituras assim tão brutais..." para logo em seguida ao contraponto da esposa afirmar peremptório: "- Ora, são desculpas fofas, atenuantes para o delito, para o crime, que não deixa de ser indignidade..." (BERTHA, 2015, p. 213). O sacramento do casamento não pode ser violado, muito embora, repetimos, em momento algum Teófilo é acusado ao trair a mulher, como se a obediência ao matrimônio fosse responsabilidade exclusivamente feminina. Mais que exemplar do machismo existente, as falas citadas de Francisco denotam a incapacidade de apreensão da leitura, motivo da tentativa de Ladice de estabelecer diálogo prazeroso. A respeito de poesia, Francisco afirma que nada mais é do que uma maneira elegante de mentira, de externar vulgaridades, embora reconheça em Teófilo um homem de caráter. A julgar as convicções de Francisco, o caráter do poeta é apenas aparente, pois o marido de Ladice desconhece o adultério e acredita que ele não pertence à boemia, que detesta e condena. Após comunicar à esposa o que pensa sobre a poesia, os poetas e a boemia, segue o diálogo exemplar da hipocrisia da sociedade: 
- Por que esse rigor, Francisco? Ela [a boemia] representa a parte candente, álacre, despreocupada, cheia de sol, de vida... Precipita-se na morte, acurvada sobre o riso... Escarnece, mas não maldiz.

- Puro engano; ela é eivada de vícios tremendos...

- Também a sociedade o é, sob a capa da hipocrisia, e dos gestos graves - replicou Ladice.

- Mas a sociedade respeita as aparências...

- Então, praticar-se o mal, às escondidas, sem testemunhas, é ser bom, virtuoso? Ah! Que sacrilégio! - exclamou ela.

- Exageras... mas que fazer se a sociedade e a vida isso reclamam?

- A sociedade, sim; mas a vida, não... A vida, Francisco, surge espontaneamente da verdade. É o homem, devido ao seu egoísmo, que a deturpa, que a desvia, que a pisa constantemente. Os preconceitos são odiosos; hão de forçosamente cair... Sinto já em mim o grito da revolta. Os que vierem triunfarão... - As narinas de Ladice fremiam emocionadas. (BERTHA, 2015, p. 173)

Desde que se obedeça as aparências da sociedade, todo o mal pode ser cometido na visão de Francisco. E é justamente o que faz Ladice, por falta de opção, apesar de não se furtar de emitir suas opiniões e brigar contra o status quo. Mais importante é a vida, independentemente da opinião pública e dos moldes sociais. Ela, ao se encontrar clandestinamente com Teófilo, cumpre a exigência hipócrita da sociedade, apesar de pretender viver sob o diapasão da coerência 
interna. A revolta e o desejo de Ladice contidos em sua última fala do excerto acima indicam mais uma afinidade com Nietzsche, que é,

no mínimo, o homem mais terrível que até agora existiu; o que não impede que eu venha a ser o mais benéfico. Eu conheço o prazer de destruir em um grau conforme a minha força para destruir - em ambos obedeço à minha natureza dionisíaca, que não sabe separar o dizer Sim do fazer Não. Eu sou o primeiro imoralista: e com isso sou o destruidor par excellence. (1995, p. 110, grifos do autor)

Ladice não detinha a mesma força do filósofo, mas Albertina Bertha, com Exaltação, sim, no sentido de que é inegável o poder da literatura, pois "Ela pode nos estender a mão quando estamos profundamente deprimidos, nos tornar ainda mais próximos dos outros seres humanos que nos cercam, nos fazer compreender melhor o mundo e nos ajudar a viver" (TODOROV, 2010, p. 76). E é essa a força contida no romance, desejoso de modificar a realidade imposta às mulheres, ou, ao menos, levar os leitores a uma reflexão mais complexa sobre o tema.

Teófilo, por sua vez, ama e é amado por Ladice. Tal qual ela, também é forçado pelos pais a se casar à revelia, sem nem mesmo ter direito a opinar sobre a decisão familiar. Ao questionar o pai sobre o casamento, recebe a resposta 
de que o negócio já estava fechado e que seria indelicado descumprir a palavra. É explícito o tratamento do casamento como negócio, cujos noivos veem seus futuros perpetuamente comprometidos. No caso de Teófilo, a relação extraconjugal é atenuante, porém o mesmo não ocorre com sua mulher, infeliz e à espera do marido, que nem sequer responde às suas cartas.

Apesar de toda sua sensibilidade, o poeta tem sentimentos contraditórios em relação a Ladice. No primeiro encontro entre ambos, em casa dele, que estava adoentado, ele afirma:

- Em vez de encontrar, nesta paixão imensa, o contentamento perfeito, a calma vertiginosa, só descubro tristeza profunda, aflitiva, cuidados torturantes... Amo-te de um amor infrene, contínuo, certo, egoísta, como se me fora obrigação ingênita... Quisera-te minha, inteira minha, um objeto, uma coisa que agarrasse, que dobrasse, que guardasse em minhas mãos, em meus bolsos, em meu peito, oculto, longe de olhos estranhos, de cobiça alheia... Mas, não; fazes parte da natureza, és luz que ofusca e atrai, és a essência forte que tonteia e que tenta a humanidade, és a mulher ardente que ama por amor do amor... - E sua cabeça pendia abatida, sombria...

Pode-se atribuir sua declaração ao estado febril em que se encontrava, mas é inegável a coisificação que ele sugere. 
A posse da mulher alheia deveria ser só sua, receoso que outro a cobiçasse como ele o faz, guardando-a em segurança nos bolsos ou nas mãos. Sofre porque sabe ser impossível a realização de tal desejo uma vez que ela pertence à natureza, ou possui sua própria natureza, livre de qualquer aprisionamento que não seja de sua vontade, a exaltação de seu amor. Tudo que Ladice sempre quis para ser feliz foi dar e receber amor de Teófilo, mas este descobre "tristeza profunda, aflitiva". Para ele, a subjetividade indecifrável da mulher amada e senhora de si o perturbava completamente, a ponto de desejar sua morte e, assim, ter a certeza de nenhum outro homem a possuir além de si. É curiosa a necessidade masculina de ter uma esposa virgem e pudica, em obediência às aparências hipócritas da sociedade, como acredita Francisco, ao passo que a busca por sexo fora do casamento é comum e encorajada. Assim inquietava-se Teófilo:

Ah! Se ela morresse! $E$ por mais que repelisse, a afugentasse, ela lá estava perversa, insistente, apoderava-se dele, tornava-se-lhe a vontade predominante, o leitmotiv de seus sentimentos, a sua alegria... - Ah! Se ela morresse - balbuciou ele finalmente. - Teria a certeza de haver sido seu único amante!... Atingiria a paz suprema. (BERTHA, 2015, p. 152-153) 
Vale lembrar que Ladice, mesmo casada, sentia-se virgem, pois dera a seu marido apenas o corpo, ou seja, sentiu-se como se de fato virgem fosse ao se relacionar com Teófilo, o que, aliás, pouca importância tinha, senão socialmente. "Não espanta que na cultura patriarcal os homens - inclusive Freud - tenham um medo terrível do feminino. Milenarmente, as mulheres são punidas pela sua sexualidade." (MURARO; BOFF, 2010, p. 163). Se por um lado Teófilo apresenta uma faceta possessiva, por outro oferecia uma visão menos preconceituosa sobre a mulher. Em diálogo com o amigo Dr. Xavier, que encontrara por acaso na rua, ao ouvir este perguntar se as mulheres não são todas iguais, responde de maneira contrária a todos os demais personagens masculinos de Exaltação:

- Para quem sai da adolescência e para quem deixou de há muito a juventude, elas todas têm a mesma linha mórbida do sexo... Ficamos ofuscados; mas, quando atingimos a virilidade, há sabores, requintes, exclusivismos, nuanças, que nos surgem na natureza; é por assim dizer o esboço do nosso ideal que se inicia; começamos então a olhá-las de um outro modo, comparamolas e divisamo-lhes as diferenças; tornamonos exigentes, queremos que a beleza estética de suas formas se rasgue e nos traga, a lume, a beleza de seu espírito; perfil grego, imaginação grega, é de tontear, é de enlouquecer - acrescentou ele, com os 
pensamentos a se refugiarem em Ladice. (BERTHA, 2015, p. 184, grifo da autora)

Ele, enfim, não mostra-se interessado apenas na beleza física de Ladice, mas procura auscultar-lhe o interior, a subjetividade, a introspecção, o caráter dionisíaco. É bastante interessante a resposta de Teófilo em um romance cujas afirmativas em torno do feminino são todas estereotipadas, dando ênfase de que as mulheres não são todas iguais e abrindo, dessa forma, na voz de um homem, ensejo para que se compreenda que elas, sendo diferentes, devem exercer atividades distintas em função de suas particularidades e atributos pessoais. Porém, apesar da compreensão positiva do poeta, ele é incapaz de compreender completamente Ladice. Assim ele se desculpa com ela:

- Eu ainda não disse tudo; há coisas em ti fugidias, que não posso fixar... A tua dor, por exemplo, quem a define? Em tua sensibilidade reverberam todos os trabalhos da humanidade e da natureza. Registras, nas sensações, mutações incríveis, intangíveis... Perdoa-me, querida, essas lacunas involuntárias. (BERTHA, 2015, p. 177)

Ele reconhece haver em Ladice "mutações incríveis", como as possui todo ser humano, caso queiramos diálogo com a crise do sujeito trabalhada por Nietzsche. Ninguém é sempre o mesmo, ponto pacífico, mas chama mais atenção 
a afirmação de Teófilo em um romance cuja temática é a emancipação feminina, até então considerada sempre igual umas às outras para, assim, realizarem as mesmas tarefas desde sempre. A incompreensão do amante é salutar para realçar o eu interior de cada personagem e de cada ser humano, enfatizando essa questão na interioridade feminina. "A liberdade, a aceitação da vida, a crítica à moral cristã, o panteísmo, o choque com as convicções e tradições arraigadas, a inversão de valores tradicionais são algumas ideias nietzschianas que Albertina Bertha incorpora em suas obras" (FAEDRICH, 2017, p. 81). Há várias outras passagens exemplares em Exaltação do machismo dominante no início do século XX, cujas falas dos demais personagens masculinos hoje soam escandalosas, mas vejamos agora mais amiúde a própria Ladice.

Ela é singular, única, extraordinária, dionisíaca. E, no romance, pretende estender tais adjetivos a todas as mulheres, muito distintas dos homens, em uma polarização entre os gêneros. O narrador incumbe-se de reverter a dominação entre os sexos da seguinte forma: "Oh! O homem é servo cabal; é sombra flagrante e inteiriça, cópia ambulante da mulher, que lhe dá a ebriez dionisíaca, a ebriez apolínea..." (BERTHA, 2015, p. 63). Ladice, ao 
constatar o poder da mulher sobre os homens, lembra, em certa medida, a personagem Pombinha, de $O$ cortiço, de Aluísio Azevedo, quando, ao finalmente menstruar, nota a maneira mendicante com que Bruno implora por reaver a esposa, apesar da traição que sofrera, como ocorre quando ele pede a Pombinha que escreva uma carta a Leocádia. Em Exaltação, a potência feminina sobre o masculino, entre outras passagens, é assim exemplificada:

Ladice sabia por seus próprios instintos que o homem cede, rende-se, submetese, é objeto, é verme, erva rasteira, valor menor, ante o carinho da mulher que traz em sua fragilidade as concepções máximas, o alarido múltiplo de mistérios que querem ser, o raio dourado da ventura que ri, o viço do imprevisto, da renovação, a mobilidade incisiva das paixões que lhe batem no sangue, quais os corações imensuráveis e ávidos da Terra fecunda. (BERTHA, 2015, p. 63)

Na realidade, há a sugestão de que, apesar da força do patriarcado a subjugar a mulher, é esta quem detém o domínio sobre o homem, quer em função do sexo, quer por razão de uma subjetividade mais aguda, irrestrita ao domínio da razão, sob a ótica psicanalista. No romance naturalista de Aluísio Azevedo, Bruno, depois da humilhação imposta pela traição de Leocádia, pede-lhe perdão e que retorne para casa. A propósito, esse é mais um exemplo da pena 
imposta à mulher adúltera: a expulsão do lar. Mas Exaltação possui uma estética bastante diversa daquela naturalista e a semelhança reside apenas nessa cena.

Não é estranha a consciência da potência que Ladice exerce sobre os homens, pois reconhece a sua força individual, por um lado, apesar de ser cônscia de sua fraqueza social, por outro, como ela mesma afirma em diálogo com Teófilo: “- Tudo em mim é forte: sou como o fogo, como a terra, como a água... Sou uma força..." (BERTHA, 2015, p. 116). O contraste de uma aparência franzina e frágil com o mistério dionisíaco e misterioso de Ladice causava admiração no poeta. A fragilidade, porém, era apenas aparente, uma vez que "o dualismo, a beleza espiritual de Ladice o inebriava. Era qualquer coisa de novo, de fresco que se Ihe apresentava à análise. Ele a achava um tipo original, cosmopolita, que tinha, no ser, a violência dos bogaris [...] Era a mulher que ele procurava [...]" (BERTHA, 2015, p. 118). Explicita-se, nessa passagem, que ela não era como as demais, pois possuía o dualismo nietzschiano, singularizando seu ente. A subjetividade e a introspecção são notórias em Ladice, exemplares no diálogo que ela trava com o cronista Armando, ao responder-lhe: "- A mulher é muito subjetiva, Sr. Armando. Queira perdoar-lhe, 
portanto, as rupturas que produz no coração bem formado dos homens..." (BERTHA, 2015, p. 122). A disparidade entre a objetividade masculina e a subjetividade feminina é latente em Ladice, que pretende, de certa forma, educá-los quanto à sua essência. Mais aprenderia o Dr. Xavier, para quem as mulheres são todas iguais, com Ladice do que com Teófilo. Talvez possamos afirmar que os leitores de Albertina Bertha, como Araripe Júnior, tenham se encantado com a forma como se posicionava uma personagem mulher em um romance de escritora do início do século XX.

O narrador, pouco adiante, nos informa que ela era filha da natureza e, como tal, tinha o direito de amar. Logo em seguida segue a cena em que se consuma o adultério, cuja descrição é romântica e poética:

Uma pequena indecisão, e Ladice batia, ligeiramente, misteriosamente, quando a porta se abriu de par em par e Teófilo pálido, fremente, a enfrentou. Como a onda que embate em outra onda, como o espaço livre que se lança contra o obstáculo resistente, como o movimento que se segue ao esforço consciente, ambos impelidos pela paixão, foram um para o outro, abraçaram-se longamente, perdidamente, silenciosamente, como os elementos, as coisas materiais, as montanhas, os rochedos que caem uns sobre os outros, a se desfazerem, misturados, rolando, fundidos, confusos, inalienáveis, perdendo a feição primitiva, assumindo 
uma nova, fazendo-se um só! Ladice inteira rendia-se à violência dessa efusão. Ela sentia pousar-lhe sobre o corpo maravilhoso de porcelana quente troféus sublimes, radiosos, sudários ardentes, rubros, tecidos pelos dedos de Afrodite. (BERTHA, 2015, p. 141)

A materialidade de seus corpos finalmente dá vazão ao eu profundo de ambos, à introspecção de cada qual, agora um só. É a exaltação do amor, que não obteve descrição quando consumou-se o casamento dela com Francisco, porque, simplesmente, não era ela que perdia sua virgindade, mas apenas um corpo oco e vazio. Vale registrar que Lóri, personagem de Clarice Lispector, ao finalmente fazer sexo com Ulisses, apesar de não ser virgem, diz-lhe que aquela é a sua primeira vez. Com Teófilo, Ladice é ela inteira, insubmissa, potente, possuindo e sendo possuída com igual paixão, sem espaço para moralismos hipócritas. Filha da natureza, era seu direito amar quem escolheu, entregar-se sem pudores. A materialidade dos rochedos se desfaz na inalienação primitiva e violenta dos instintos humanos. É desnecessária uma narração mais exata do que ocorreu, pois percebe-se claramente o fim a que Ladice sempre almejou. A partir dessa cena, os encontros entre os amantes são diários. Poucas páginas à frente, ela diz a Teófilo: “- Espera, eu te peço... É na imobilidade, no silêncio, que te sinto em mim 
mesma, que vou além de ti. - E ela parecia beber êxtases supremos" (BERTHA, 2015, p. 147). A forma como uma mulher extasia-se merece registro, pois, salvo engano, é essa uma das primeiras vezes, senão a primeira, em que uma escritora cria uma cena de sexo sob a ótica feminina. Não há espécie alguma de moralismo na narrativa, pois este não cabia nem à personagem nem à autora, mas houve críticas contundentes à época sobre o romance, aconselhando não ser lícita a leitura.

Exaltação é um romance riquíssimo e que renderia ensaio mais denso e complexo, cujas proposições de leituras não se esgota nessas poucas páginas. A estratégia narrativa de colocar holofote sobre o feminino e sobre a sociedade patriarcal não pretende apartar homens e mulheres, justo o contrário; antes, sugere que haja igualdade de gêneros e que ambos coexistam de forma harmoniosa e respeitosa, avesso à hipocrisia social. Teófilo, apesar de seus defeitos, reivindica também a compreensão da mulher e é, em certa medida, a razão de vida de Ladice. Ou melhor, o amor que ela nutre por ele dá substrato à luta da protagonista. Mas em momento algum do romance fica a indicação de uma "guerra dos sexos", mas sim da reivindicação de que a sociedade abdique dos preconceitos vigentes. Do mesmo modo que 
em Uma aprendizagem ou o livro dos prazeres, de Lispector, Ulisses é paciente e atencioso para com Lóri, aqui Teófilo em certa medida funde-se com Ladice, seja na relação carnal do amor clandestino, seja no caráter dionisíaco de ambos. Em carta que Ladice escreve ao amante em momento de viagem a Petrópolis, essa união é bem clara:

Meu amigo,

Eu não sou mais a mesma... Sou o teu corpo, e toda a tua inviabilidade, a tua crença, a tua paixão, o teu capricho, a tua força, o teu romantismo, a tua ideia... trago nos olhos, os teus olhares quentes, perfumados, esses olhares que atiravam sobre mim a tua agonia, a tua sensação, o determinismo sublime de teu ser... Esses teus olhares que me imobilizam, que me fazem viver em ti com obstinação... Rio como tu ris, falo como tu falas... finjo trazer nos gestos, no meu silêncio, em minhas tendências, essa tua extravagância oriental, sombria, extraordinariamente perturbante que aprendeste com as mulheres de Constantinopla, com as gregas... Todo o mundo diz: não és a mesma... Parece que sofreste, que, gozaste muito, que viajaste, que adquiriste experiências, conhecimentos, que estudastes...

Sorrio, Oh! Eles não sabem dos esplendores que carrego em meu seio...

Estou separada de ti, porém em ti... Recebe o beijo de minha alma... Leva-te, entusiasmo, vida, juventude, loucura, intemperança, efervescência, amor de ti mesmo... Ladice. (BERTHA, 2015, p. 156) 
Albertina Bertha exalta o amor, possível apenas se houver respeito e igualdade entre ambos os gêneros, e Ladice é uma mulher exemplar na luta contra o patriarcado e a hipocrisia social - batalha empunhada também em nome da liberdade e do amor. Esperamos que Exaltação saia do ostracismo e encontre seu devido lugar na literatura brasileira, não apenas porque sua temática ainda hoje é bastante atual, mas também porque esteticamente merece atenção. Nosso desejo é que a literatura de autoria feminina, em um futuro próximo, como sugere Eurídice Figueiredo (2020), abandone o adjunto adnominal e seja reconhecida como literatura.

\section{REFERÊNCIAS}

BERTHA, Albertina. Exaltação. Porto Alegre: Gradiva; Rio de Janeiro, Fundação Biblioteca Nacional, 2015.

COELHO, Nelly Novaes. Dicionário crítico de escritoras brasileiras. São Paulo: Escrituras Editora, 2002.

DEL PRIORI, Mary. Ao sul do corpo: condição feminina, maternidade e mentalidades no Brasil Colônia. São Paulo: EdUNESP, 2009.

FAEDRICH, Anna. O romance de introspecção no Brasil: o lugar de Albertina Bertha. Novas Edições Acadêmicas, 2017. [e-book].

FIGUEIREDO, Eurídice. Por uma crítica feminista: leituras transversais de escritoras brasileiras. Porto Alegre: Zouk, 2020.

LISPECTOR, Clarice. Uma aprendizagem ou o livro dos prazeres. Rio de Janeiro: Rocco, 1998.

MACHADO, Roberto. O nascimento do trágico: de Schiller a Nietzsche. Rio de Janeiro: Jorge Zahar Ed., 2006. 
MURARO, Rose Marie; BOFF, Leonardo. Feminino e masculino: uma nova consciência para o encontro das diferenças. Rio de Janeiro: Record, 2010. NIETZSCHE, Friedrich. Ecce homo: como alguém se torna o que é. São Paulo: Companhia das Letras, 1995.

NIETZSCHE, Friedrich. O nascimento da tragédia ou helenismo e pessimismo. São Paulo: Companhia das Letras, 1992.

TODOROV, Tzvetan. A literatura em perigo. Rio de Janeiro: Difel, 2010.

\section{Bruno Lima}

Doutor em Literatura Comparada pela UERJ.

Possui vínculo com o programa de pós-graduação da Faculdade Unyleya.

Lattes: $\underline{\text { http://lattes.cnpq.br/5624685591476091 }}$

E-mail bruno.lima ri@hotmail.com

ORCID iD: https://orcid.org/0000-0001-9464-4293 